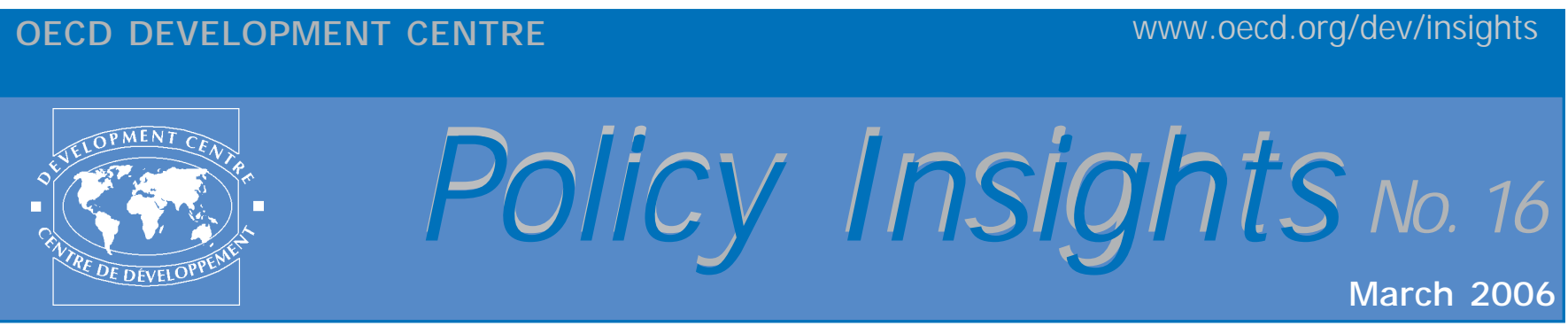

\title{
The Gender, Institutions and Development Data Base
}

by J ohannes Jütting, Christian Morrisson, Jeff Dayton-J ohnson and Denis Drechsler

- Recent experience in Finland, Germany, Chile and Liberia demonstrates that women can take top government positions.

- Yet, some traditions and socio-cultural norms trap countries in poverty as they bar women from economic activities - more discrimination, less growth, more poverty!

- Coherent, culturally-sensitive and inclusive strategies remove counterproductive discrimination.

The GI D-DB - A quality resource for better policies

The Gender, Institutions, and Development Data Base (GIDDB) represents a new tool for researchers and policy makers to determine and analyse obstacles to women's economic development (accessible at www.oecd.org/dev/gender). It covers a total of 161 countries and comprises an array of 60 indicators on gender discrimination. The data base has been compiled from various sources and combines in a systematic and coherent fashion the current empirical evidence that exists on the socio-economic status of women. Its true innovation is the inclusion of institutional variables that range from intra-household behaviour to social norms. Information on cultural and traditional practices that impact on women's economic development is coded so as to measure the level of discrimination. Such a comprehensive overview of gender-related variables and the data base's specific focus on social institutions make the GID-DB unique, providing a tool-box for a wide range of analytical queries and allowing case-by-case adaptation to specific research or policy questions.

\section{What distinguishes the GID-DB from existing compllations?}

Discrimination against women has multiple facets. It is becoming increasingly evident that social institutions comprising informal laws, customs, and traditions are an important factor determining the extent to which women can participate in social and economic life. Accordingly, the GID-DB introduces a set of innovative indicators that can be grouped into four categories:

i) Family Code, including information on marriage customs (age, inheritance, and polygamy) and decisionmaking power within a household (parental authority, repudiation).

ii) Physical I ntegrity, capturing violence against women through traditional practices such as female genital mutilation or other attacks (e.g. rape, assault, harassment).

iii) Civil Liberties, measuring the extent to which women can participate in social life (e.g. moving freely in public without the obligation to wear a veil or be escorted by male relatives).

iv) Ownership Rights, indicating the quality of women's most basic economic right - to hold property, either in the form of bank loans, land, or other material assets.

\section{Application and Use of the GI D-DB}

Preliminary analyses using the GID-DB clearly indicate the relevance of social institutions for understanding the economic role of women. There is strong indication that higher values of discriminatory social institutions are associated with lower rates of women's participation in the labour market (Figure 1). 
Figure 1. Social Institutions and Women's

Participation in the Labour Market

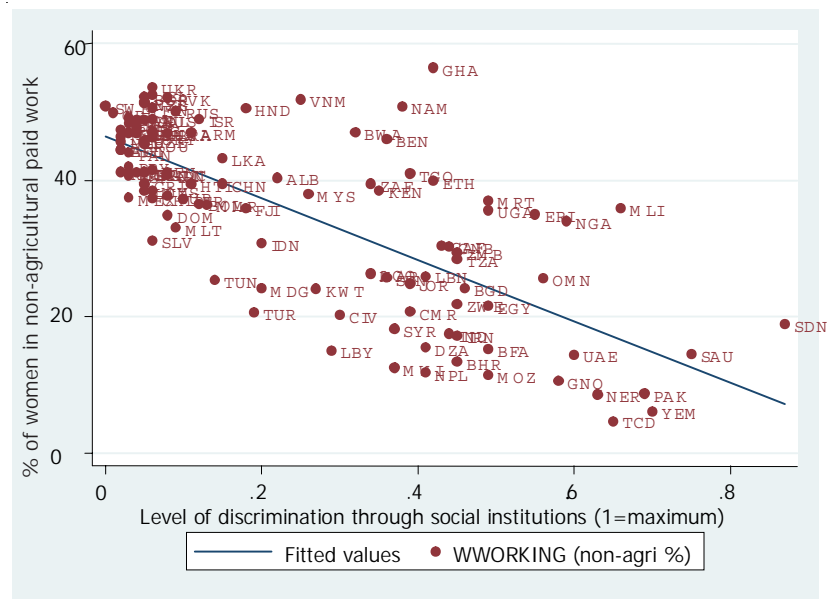

The explanatory variable uses the arithmetic average of all subsectors of social institutions; a value of $1(0)$ indicates the highest (lowest) level of discrimination.

Source: Jütting et al. (2006).

Discriminatory social institutions have a direct impact on women's economic development. A low level of ownership rights, for example, stalls entrepreneurial behaviour. They also exert an indirect influence by affecting women's access to resources - violence against women damages health and thus women's chances in the labour market. Indeed these negative relationships are more pronounced than the positive correlation between a country's level of income and women's participation in the economy.

\section{Looking ahead}

The Gender, Institutions, and Development Data Base (GIDDB) makes an important contribution to the gender debate, in particular because it incorporates institutional obstacles to women's economic development. Our initial econometric analysis suggests that the quantitative significance of institutional factors might even override more commonly used variables such as income per capita. This finding supports the interpretation that an improvement of the economic role of women will not necessarily follow an increase in the level of income. Rather, policy measures - such as the recent reforms to the family code in Morocco - have to be implemented that directly address institutional bottlenecks. In this respect, the GID-DB helps to identify policies that tackle the roots rather than the symptoms of gender discrimination.

\section{Further reading:}

J ütting, J., C. Morrisson, J. Dayton-J ohnson and D. Drechsler, Measuring Gender (In)Equality, OECD Development Centre Working Paper No. 247.

www.oecd.org/dev/insights

www.oecd.org/dev/briefs

www.oecd.org/dev/wp

Readers are encouraged to quote or reproduce material from $O E C D$ Development Centre Policy Insights for their own publications. In return, the Development Centre requests due acknowledgement and a copy of the publication. Full text of Policy Insights and more information on the Centre and its work are available on its web site:

www. oecd.org/dev
OECD Development Centre 2, rue André-Pascal, 75775 Paris Cedex 16, France Tel.: +33-(0) 145.24 .82 .00 Fax: +33-(0)1 44306149 E-mail: dev.contact@oecd.org 